\title{
Is pelvic mapping applicable in iliosacral screw fixation to determine screw entry point and screw trajectory?
}

\author{
İliosakral vida sabitlemede vida giriş noktası ve vida yöneliminin belirlenmesinde \\ pelvik haritalama uygulanabilir mi?
}

\author{
Serhat Durusoy, $\mathrm{MD}^{1}{ }^{1}$, Ahmet Emre Paksoy, $\mathrm{MD}^{1}{ }^{1}$, Murat Korkmaz, $\mathrm{MD}^{1}{ }^{\mathbb{D}}$, \\ Ahmet Şükrü Solak, MD'1D, Bülent Dağlar, $M^{2}{ }^{2} \mathbb{B}$ \\ 'Department of Orthopedics and Traumatology, Yozgat Bozok University Faculty of Medicine, Yozgat, Turkey \\ ${ }^{2}$ Department of Orthopedics and Traumatology, Güven Hospital, Ankara, Turkey
}

\begin{abstract}
Objectives: This study aims to investigate if pelvic mapping is applicable in iliosacral screw fixation to determine screw entry point and screw trajectory.

Patients and methods: Clinical files and images of 16 patients (10 males, 6 females; mean age 35 years; range, 20 to 57 years) who underwent iliosacral screw fixation due to sacroiliac joint injury and sacrum fracture were retrospectively reviewed. Pelvic mapping was performed using preoperative tomography images of the patients and appropriate screw entry point and trajectory were determined. Postoperative computed tomography scans of all patients were obtained and these were used to evaluate the accuracy of the screw position.
\end{abstract}

Results: No intraoperative complications occurred. The entry points and trajectory of the screws were compatible for all patients pre- and postoperatively.

Conclusion: Mapping of the pelvis is a method that can be used for preoperative planning of iliosacral screwing.

Keywords: Iliosacral screw fixation, mapping method, pelvic fracture, percutaneous fixation, sacroiliac joint.

Pelvis injuries account for approximately $3 \%$ of all skeletal injuries..$^{[1]}$ In unstable fractures, morbidity and mortality rates are particularly high, requiring surgery to provide stability and prevent potential morbidities

\section{ÖZ}

Amaç: $\mathrm{Bu}$ çalışmada, iliyosakral vida sabitlemede vida giriş noktası ve vida yöneliminin belirlenmesinde pelvik haritalamanın uygulanabilir olup olmadığı araştırıldı.

Hastalar ve yöntemler: Sakroiliyak eklem yaralanması ve sakrum kırı $\breve{g}$ nedeniyle iliyosakral vida sabitleme uygulanan 16 hastanın (10 erkek, 6 kadın; ort. yaş 35 yıl; dağılım, 20-57 yıl) klinik dosyaları ve görüntüleri retrospektif olarak incelendi. Hastaların ameliyat öncesi tomografi görüntüleri kullanılarak pelvik haritalama yapıldı ve uygun vida giriş noktası ve yönelimi belirlendi. Tüm hastaların ameliyat sonrası bilgisayarlı tomografi taramaları alındı ve bunlar vida pozisyonunun doğruluğunu değerlendirmek için kullanıldı.

Bulgular: Ameliyat sirasında herhangi bir komplikasyon gelişmedi. Vidaların giriş noktaları ve yönelimleri ameliyat öncesi ve sonrasında tüm hastalar için uyumluydu.

Sonuç: Pelvisin haritalanması, iliyosakral vidalamanın ameliyat öncesi planlamasında kullanılabilecek bir yöntemdir.

Anahtar sözcükler: İliyosakral vida sabitleme, haritalama yöntemi, pelvik kırığı, perkütanöz sabitleme, sakroiliyak eklem.

and mortality. ${ }^{[2]}$ In posterior pelvis fractures and dislocations, surgery can be performed with an open or percutaneous approach; however, the latter has become the preferred mode of treatment in recent years. ${ }^{[3,4]}$ 
Performing a percutaneous approach requires comprehensive planning of the surgery, appropriate perioperative use of imaging techniques, and intraoperative correlation of a variety of data, as well as an advanced surgical experience. ${ }^{[5]} \mathrm{A}$ deeper understanding of the regional anatomical structures and competence in three-dimensional conceptualization are the critical competencies required to be held by the performing surgeon. ${ }^{[3]}$ Potential complications may include nerve damage, vascular damage or inappropriate screw placement when surgery is performed with this technique.

Introduction of new surgical techniques including the computed tomography (CT)-based and computer navigation-assisted techniques reduced the complication rates; however, the need to decrease the untoward consequences of the surgery still remains. ${ }^{[6]}$ Furthermore, several studies have reported a number of deficiencies in the description of these techniques. ${ }^{[7,8]}$ Today, fluoroscopy and conventional radiographs are still the most commonly used preoperative imaging methods to perform percutaneous iliosacral screw fixation compared to the use of CT and other computer-assisted techniques. In this study, we aimed to investigate if pelvic mapping is applicable in iliosacral screw fixation to determine screw entry point and screw trajectory. ${ }^{[9]}$

\section{PATIENTS AND METHODS}

The study was conducted at Yozgat Bozok University Faculty of Medicine between May 2016 and 2017 and included 16 patients (10 males, 6 females; mean age 35 years; range, 20 to 57 years) who underwent iliosacral screw fixation due to sacroiliac joint injury and sacrum fracture. Patients who had preoperative $\mathrm{CT}$ images, intraoperative fluoroscopic or X-ray images and postoperative $\mathrm{CT}$ images were included. The study protocol was approved by the Yozgat Bozok University Ethics Committee (decision no: 2017/KAEK-189_2018.04.25_05). A written informed consent was obtained from each patient. The study was conducted in accordance with the principles of the Declaration of Helsinki.

The perioperative mapping technique is used in six stages to determine the accurate screw entry points and to establish appropriate trajectories. A combination of commonly used imaging methods including $\mathrm{CT}$, fluoroscopy, and radiograms are used in this mapping technique.

While performing iliosacral screwing, we use six planes (planes 1, 2, 3, 4, 5, 6) that we generate according to anatomical references, and five regions between the planes (A, B, C, D, E regions). The planes 1, 2, 3 are generated on axial $C T$ images, while the planes $4,5,6$ are generated on outlet X-ray or fluoroscopy images. When these planes are combined, the sacrum will be divided into six regions in the lateral plane.

Axial CT images are used for mapping the pelvis in the axial plane. Three planes are determined on axial $\mathrm{CT}$ images in accordance with the anatomical reference points (Figure 1a). Plane 1 is the plane passing through the anterior margin of the sacral vertebral bodies. Plane 2 is the plane passing through the posterior of the sacral vertebral bodies. Plane 3 is the plane passing through the posterior margin of the spinal canal. These three planes divide the pelvis into three regions (A, B, C regions) (Figure 1a). The schematic drawing of the reflections of these regions

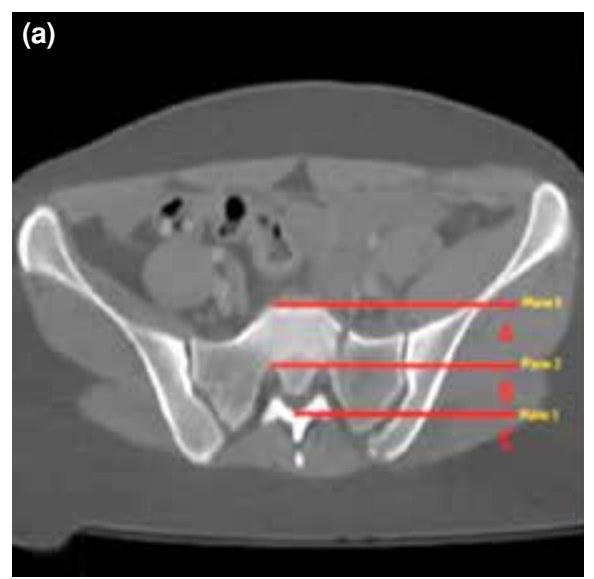

(b)

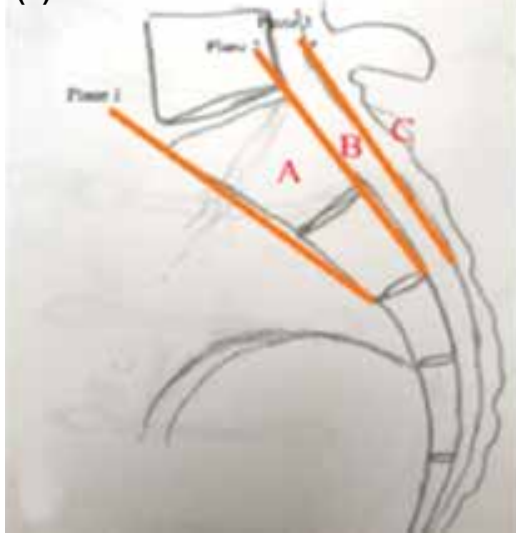

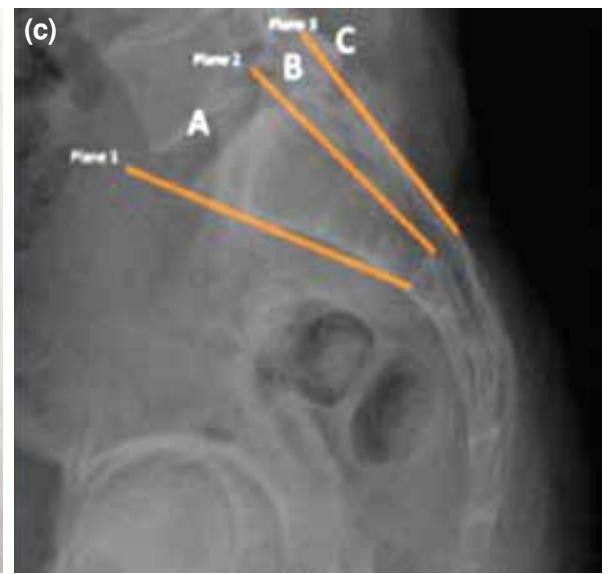

Figure 1. (a) Generation of planes 1, 2, 3 on axial computed tomography (CT) images and A, B, C regions between planes. (b) Image of regions determined on axial CT on schematic drawing of lateral radiograph. (c) Image of regions determined on axial CT on lateral radiograph. 

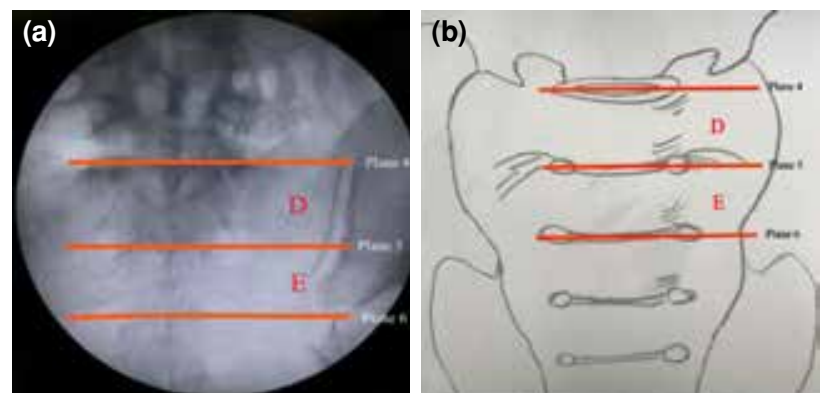

(c)
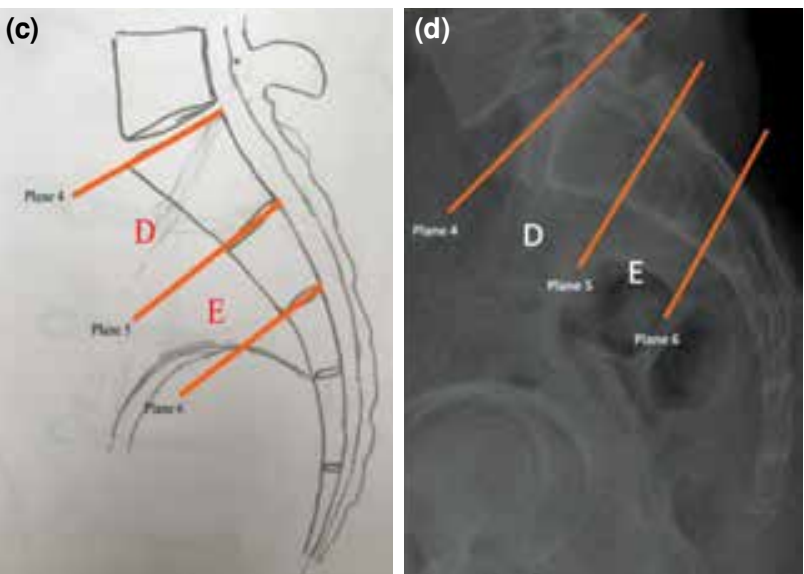

Figure 2. (a) Determination of planes 4, 5, 6 on outlet $X$-ray images and $D, E$ regions. (b, c) Image of regions and planes on schematic drawing of lateral and outlet radiograph. (d) Projections of planes and regions on lateral radiograph.

in the lateral plane and their appearance on X-ray are shown in Figures $1 b$ and $c$. These regions are used to adjust the anterior posterior position of the screw entry. These regions determined on preoperative CT images can also be adjusted on intraoperative inlet radiograph.

In mapping of the pelvis in the sagittal plane, the outlet image of the pelvis is used. Three planes are determined on the outlet radiograph of the pelvis in accordance with the anatomical reference points (Figure 2a). Plane 4 is the plane passing through the upper margin of the S1 vertebral body. Plane 5 is the plane passing through the S1-S2 intervertebral disc space. Plane 6 is the plane passing through the S2-S3 intervertebral space. These planes divide the sacrum into two regions ( $\mathrm{D}$ and $\mathrm{E}$ regions). These regions are used to adjust the sagittal position of the screw entry. Particularly in individuals with dysmorphic pelvic anatomy, it would be appropriate to insert the screw from the lower region (E region). The outlet and lateral views of the new planes and regions generated on the outlet radiographs are shown in Figure 2.

In this stage, all planes and regions obtained in the previous stages are combined (Figure 3). Six intersection regions are created as a result of the intersection of the regions obtained in the previous stages ( $\mathrm{AD}, \mathrm{BD}, \mathrm{CD}, \mathrm{AE}, \mathrm{BE}, \mathrm{CE}$ regions). We used these regions to determine the location of the screw entry point.

At this stage of the mapping process, a safe screw corridor with potential screw entry sites in the bone is determined on the axial plane CT images so that the screw can be advanced after its insertion (Figure 4).
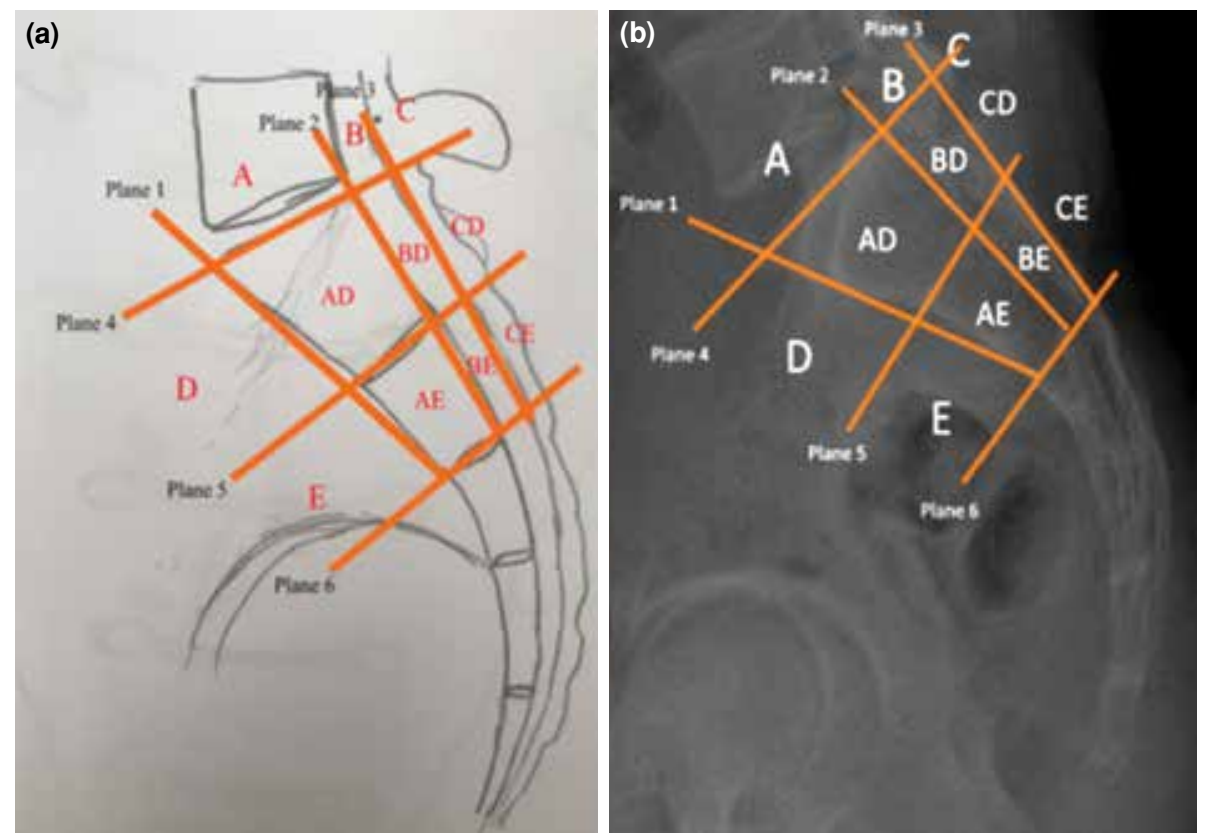

Figure 3. (a) Schematic drawing of planes and regions and, (b) their projections on lateral radiograph. 

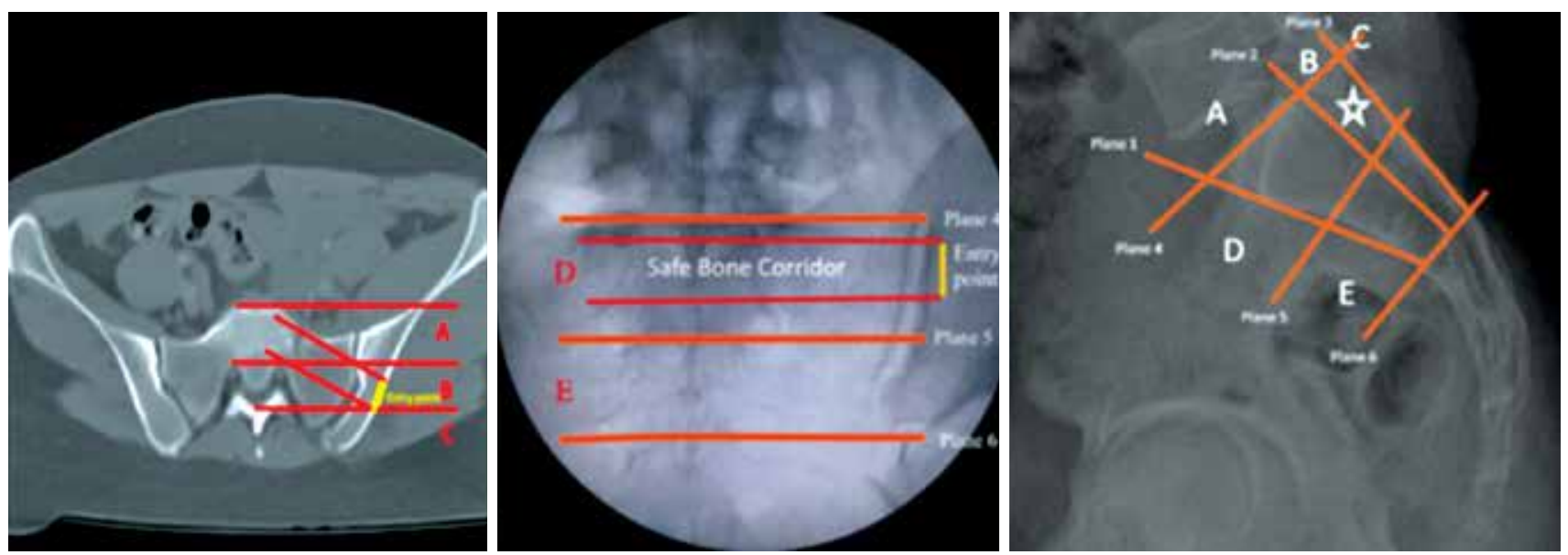

Figure 4. Determination of screw entry points and safe surgical corridors in different planes.

The establishment of a safe corridor in the bone is critical to prevent potential damages to the cortices during the course of the screw. Any injuries to the bone cortices can cause morbidity or even mortality. Figure 4 shows a safe screw corridor and associated entry points, which were determined in the CT image and outlet fluoroscopy view of a patient. An important parameter to be used in the designation of the corridor is the screw diameter. If the screw to be used has a diameter of $6.5 \mathrm{~mm}$, the corridor must be confirmed on at least four consecutive CT slices taken at $2 \mathrm{~mm}$ intervals. Evaluations based on a single CT slice can result in untoward outcomes.

In the preoperative determination of the screw entry, the location of the screw entry in the anterior posterior position is determined by axial CT images, while the sagittal position is determined by outlet radiograph (Figure 4). As seen in Figure 4, the location of the screw entry should be in the $B$ region in the anterior posterior position and in the $\mathrm{D}$ region in the sagittal position (BD region).

The aim of this technique is that the tip of the screw engages in the S1 vertebral body. In this mapping technique, the body of the S1 vertebra remains in the $\mathrm{AD}$ region in any case. Therefore, it should be confirmed whether or not the tip of the screw ends in the $\mathrm{AD}$ region when screwing is performed.

The last stage is checking the anteroposterior and sagittal orientations of the K-guidewire on the inlet and outlet radiographs, respectively, after its insertion from the calculated entry point. If required, the K-guidewire can be proceeded or adjusted. Therefore,
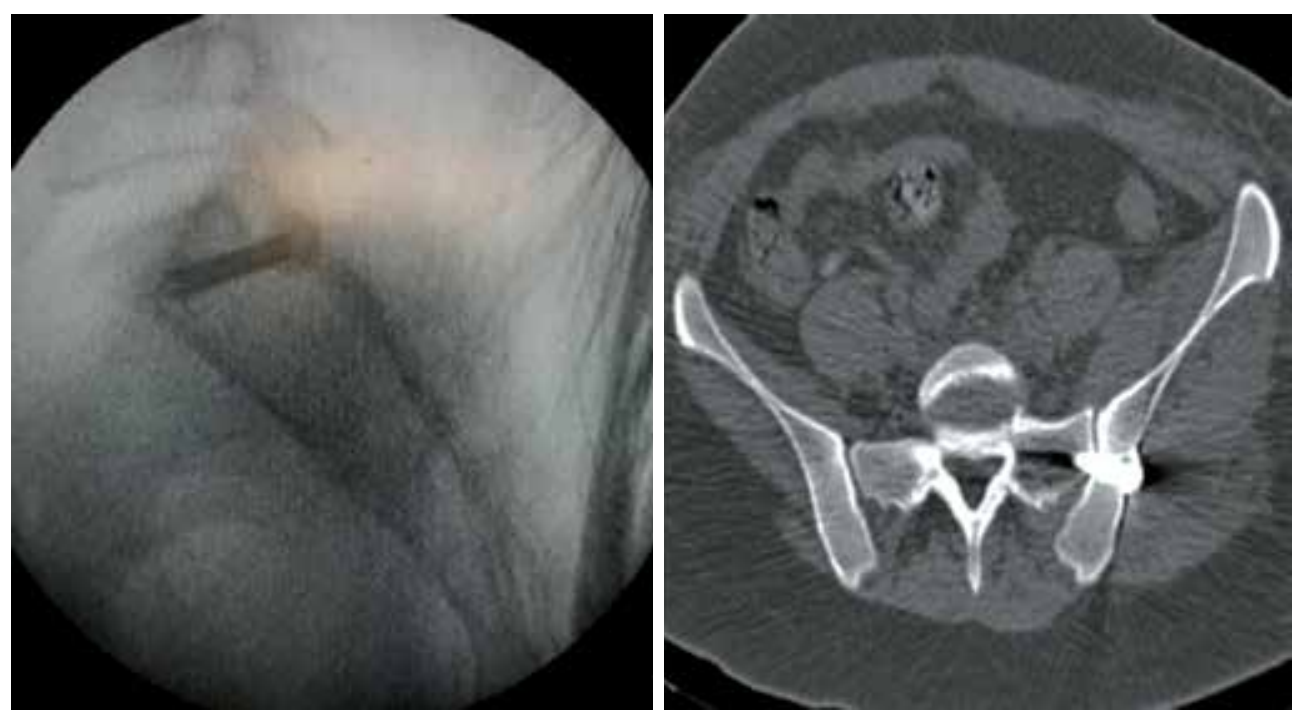

Figure 5. Postoperative screw position in axial computed tomography image and lateral radiograph. 
it is ensured that it remains within the surgical safe bone corridor. After the procedure has been completed, the suitability of the screw location should be confirmed by postoperative X-ray and computed tomography (Figure 5).

\section{Statistical analysis}

Statistical analysis was performed using the IBM SPSS version 24.0 software (IBM Corp., Armonk, NY, USA).

\section{RESULTS}

Closed reduction was performed in all 16 patients. No intraoperative complications emerged. Postoperative complications included superficial infection in one patient and pulmonary embolism in one patient. Pulmonary embolism developed during the hospital stay in one patient who later died.

Postoperative CT scans were obtained in all patients and used for evaluating the accuracy of the position of the screw. Screw placement was fully accurate in 14 patients, being completely inserted into the cancellous bone. In the remaining two patients, only a cortical contact occurred without penetration. No revision surgeries were performed in any of the patients for sacroiliac fixation.

\section{DISCUSSION}

Percutaneous iliosacral screw fixation is a surgical method commonly performed in the fractures involving the posterior pelvis. This fixation technique has become a more commonly preferred technique compared to the open surgical approaches in recent years for the treatment of injuries to the posterior pelvis. ${ }^{[10,11]}$ The percutaneous approach employed for screw fixation is reported to be associated with low risk of damage to the soft tissues and low infection rates. ${ }^{[8,12]}$ This method requires good surgical planning in the preoperative period, along with advanced skills and experience of the surgeon. ${ }^{[5,13]}$ The critical steps of the technique include a well-organized and comprehensive preoperative planning, the acquisition of good quality images with fluoroscopy, the precise determination of the screw entry point, and ensuring accurate screw orientation. Due to the individual anatomical variations in the structure of the pelvis, the error margin is considerably low in all of these steps. Therefore, one can argue that a reduction in the margin of error will allow for reducing the complication rates, raising the requirement for the introduction of newly developed surgical methods.

The aim of the iliosacral screw fixation in the classical approach is to insert the screw directly targeting the body of the S1 vertebra in the lateral plane. During the process of fixation, the tip of the screw should be in contact with the body of the S1 vertebra, which has a compact structure. ${ }^{[8]}$ It should always be remembered that the targeted area for the screw tip (S1 body) and the entry point of the screw can be different. ${ }^{[14]}$ Failure to determine the entry point appropriately may cause the screw not to remain in the safe bone corridor, leading to an increased risk of untoward complications. ${ }^{[15-17]}$

Although the target of the screw is the S1 body in the classical technique, recent studies indicate that the access of the screw to the opposite sacroiliac joint (transiliac-transsacral screwing) is more appropriate in terms stability. Particularly in the elderly osteoporotic patient population, the engagement of the screw in the $\mathrm{S} 1$ body may not provide adequate fixation..$^{[18,19]}$ It would therefore be appropriate for the screw to reach the opposite sacroiliac joint.

Difficulties in defining the accurate entry point can mainly be associated with the following factors including the individual variations in the anatomy of the sacrum, ${ }^{[13]}$ inadequate imaging techniques, and an insufficient combination of the preoperative $\mathrm{CT}$ and intraoperative fluoroscopy images. In the literature, this point of view is supported by Giannoudis et al. ${ }^{[20]}$ Another study by Bastian et al. ${ }^{[6]}$ stated that age and gender were the inherent patient factors associated with the variations in screw entry points. The anatomical structure of the sacrum was categorized into three types as ascending, descending or horizontal types by Goetzen et al. ${ }^{[21]}$ It was also stated that an additional dysmorphic structure could be observed in the sacrum. The anatomical structure of the pelvis should be taken into consideration in transiliac-transsacral screwing. According to Goetzen et al., ${ }^{[21]}$ transiliac-transsacral screwing is appropriate for people with horizontal and descending type sacrum, while transiliac-transsacral screwing may not be appropriate for people with ascending type and dysmorphic sacrum morphology. In such cases, screwing engaged in the $\mathrm{S} 1$ body should be performed. This categorization of the different anatomical types of the sacrum by Goetzen et al. ${ }^{[21]}$ supports the view that the screw entry points should be determined uniquely for every patient, requiring comprehensive planning in the preoperative period.

The potential difficulties in the application of the percutaneous fixation technique include an appropriate duration of the training and the experience of the surgeon, individual patient variations in the anatomy of the sacrum such as the sacral dysmorphism, and other patient-related 
factors such as obesity or intestinal accumulation of excess amounts of gas. ${ }^{[11]}$ Furthermore, factors related to the injury including the impossibility of reduction or injuries in the screw entry point, and the need for advanced imaging techniques can cause difficulties, too. To overcome these difficulties, new methods of $\mathrm{CT}$ and computer-assisted navigation screw fixation techniques are continuously being developed and introduced. ${ }^{[7,8,22,23]}$ However; high costs, low utility, and rare availability of CT and computer navigation-assisted techniques lead to significantly infrequent use of these techniques. Therefore, the iliosacral screw fixation technique performed under fluoroscopy guidance is currently the most commonly used method.

The fluoroscopy-guided percutaneous iliosacral screw fixation technique requires a precise application of a safe bone corridor for the screw to have proceeded. If this cannot be accomplished, significant complications may occur including vascular and neurological injuries. The most frequent injuries occur in the L5 nerve root. Several studies in the literature have reported that neurological defects may be seen at rates from 0.5 to $7.7 \% .{ }^{[3]}$ Malposition of the screws can be another complication reported at rates in the range between 2 to $29 \% .{ }^{[24-26]} \mathrm{A}$ study by Osterhoff et al. ${ }^{[27]}$ reported screw malpositioning at a rate of $4 \%$, nerve damage at $2 \%$, and non-union at a rate of $1 \%$. The same study reported that revision surgery was required for $4 \%$ of the patients undergoing iliosacral screw fixation. Good coordination of the surgical procedure with the fluoroscopy images intraoperatively may allow for avoiding these complications.

Iliosacral screwing is successfully used in the treatment of fractures and dislocations of the posterior pelvis. Although pelvic mapping is an appropriate method in preoperative planning during the use of this technique, attention should be drawn to one point: We recommend that pelvic mapping be performed following the appropriate reduction, particularly in the case of pelvic fractures with vertical instability. In the case of inappropriate reduction, the anatomical integrity of the sacrum and iliac wing will be impaired. Thereby, the screw entry point determined will change. Care should be exerted in this regard in order to avoid undesirable complications.

In this study, we have tested a practical and easily applicable method for the determination of the screw entry point. A mapping technique was applied using the CT and X-ray or fluoroscopy images of the sacrum and it was used as an intraoperative guiding method. It was demonstrated that the screw entry point found on the lateral radiograms could actually be different when the mapping method was applied. A preoperative comprehensive surgical planning along with an appropriate use and evaluation of the fluoroscopy technique is of major importance to avoid complications.

This study has some limitations. The sample size was not large which may affect results. In order to reveal the error margin of the technique, high number of patients is needed. The success of this technique should be confirmed by different surgeons in larger patient series.

In conclusion, the mapping technique for the pelvis described in this study is an extremely simple and useful method with no additional costs, which can be used in determining the screw entry point precisely, ensuring the appropriate screw orientation. It is suggested that the difficulties experienced during the surgery can be reduced with this technique. Therefore, this technique may be a guide for surgeons, particularly for those who will begin to perform the percutaneous iliosacral screw fixation surgery.

\section{Declaration of conflicting interests}

The authors declared no conflicts of interest with respect to the authorship and/or publication of this article.

\section{Funding}

The authors received no financial support for the research and/or authorship of this article.

\section{REFERENCES}

1. Failinger MS, McGanity PL. Unstable fractures of the pelvic ring. J Bone Joint Surg [Am] 1992;74:781-91.

2. Keating JF, Werier J, Blachut P, Broekhuyse H, Meek RN, O'Brien PJ. Early fixation of the vertically unstable pelvis: the role of iliosacral screw fixation of the posterior lesion. J Orthop Trauma 1999;13:107-13.

3. van den Bosch EW, van Zwienen $C M$, van Vugt $A B$. Fluoroscopic positioning of sacroiliac screws in 88 patients. J Trauma 2002;53:44-8.

4. Latenser BA, Gentilello LM, Tarver AA, Thalgott JS, Batdorf JW. Improved outcome with early fixation of skeletally unstable pelvic fractures. J Trauma 1991;31:28-31.

5. Routt ML Jr, Simonian PT, Agnew SG, Mann FA. Radiographic recognition of the sacral alar slope for optimal placement of iliosacral screws: a cadaveric and clinical study. J Orthop Trauma 1996;10:171-7.

6. Bastian JD, Jost J, Cullmann JL, Aghayev E, Keel MJ, Benneker LM. Percutaneous screw fixation of the iliosacral joint: optimal screw pathways are frequently not completely intraosseous. Injury 2015;46:2003-9.

7. Pieske O, Landersdorfer C, Trumm C, Greiner A, Wallmichrath J, Gottschalk O, et al. CT-guided sacroiliac percutaneous screw placement in unstable posterior pelvic ring injuries: accuracy of screw position, injury reduction and complications in 71 patients with 136 screws. Injury 2015;46:333-9. 
8. Radetzki F, Wohlrab D, Goehre F, Noser H, Delank KS, Mendel T. Anatomical conditions of the posterior pelvic ring regarding bisegmental transverse sacroiliac screw fixation: a 3D morphometric study of 125 pelvic CT datasets. Arch Orthop Trauma Surg 2014;134:1115-20.

9. Atik OŞ. Which articles do we prefer to publish? Eklem Hastalik Cerrahisi 2018;29:1.

10. Matta JM, Saucedo T. Internal fixation of pelvic ring fractures. Clin Orthop Relat Res 1989;242:83-97.

11. Iorio JA, Jakoi AM, Rehman S. Percutaneous Sacroiliac Screw Fixation of the Posterior Pelvic Ring. Orthop Clin North Am 2015;46:511-21.

12. Routt ML Jr, Kregor PJ, Simonian PT, Mayo KA. Early results of percutaneous iliosacral screws placed with the patient in the supine position. J Orthop Trauma 1995;9:207-14.

13. Miller AN, Routt ML Jr. Variations in sacral morphology and implications for iliosacral screw fixation. J Am Acad Orthop Surg 2012;20:8-16.

14. Wagner D, Kamer L, Rommens PM, Sawaguchi T, Richards RG, Noser H. 3D statistical modeling techniques to investigate the anatomy of the sacrum, its bone mass distribution, and the trans-sacral corridors. J Orthop Res 2014;32:1543-8.

15. Altman DT, Jones CB, Routt ML Jr. Superior gluteal artery injury during iliosacral screw placement. J Orthop Trauma 1999;13:220-7.

16. Maled I, Velez R, Lopez R, Batalla L, Caja VL. Pseudoaneurysm of the superior gluteal artery during iliosacral screw fixation. Acta Orthop Belg 2007;73:544-7.

17. Collinge C, Coons D, Aschenbrenner J. Risks to the superior gluteal neurovascular bundle during percutaneous iliosacral screw insertion: an anatomical cadaver study. J Orthop Trauma 2005;19:96-101.

18. Zhao Y, Zhang S, Sun T, Wang D, Lian W, Tan J, et al. Mechanical comparison between lengthened and short sacroiliac screws in sacral fracture fixation: a finite element analysis. Orthop Traumatol Surg Res 2013;99:601-6.

19. Pulley BR, Cotman SB, Fowler TT. Surgical Fixation of Geriatric Sacral U-Type Insufficiency Fractures: A Retrospective Analysis. J Orthop Trauma 2018;32:617-22.

20. Giannoudis PV, Papadokostakis G, Alpantaki K, Kontakis $\mathrm{G}$, Chalidis B. Is the lateral sacral fluoroscopic view essential for accurate percutaneous sacroiliac screw insertion? An experimental study. Injur. 2008;39:875-80.

21. Goetzen M, Ortner K, Lindtner RA, Schmid R, Blauth M, Krappinger D. A simple approach for the preoperative assessment of sacral morphology for percutaneous SI screw fixation. Arch Orthop Trauma Surg 2016;136:1251-7.

22. Mendel T, Radetzki F, Wohlrab D, Stock K, Hofmann GO, Noser H. CT-based 3-D visualisation of secure bone corridors and optimal trajectories for sacroiliac screws. Injury 2013;44:957-63.

23. Beck M, Kröber M, Mittlmeier T. Intraoperative threedimensional fluoroscopy assessment of iliosacral screws and lumbopelvic implants stabilizing fractures of the os sacrum. Arch Orthop Trauma Surg 2010;130:1363-9.

24. Templeman D1, Schmidt A, Freese J, Weisman I. Proximity of iliosacral screws to neurovascular structures after internal fixation. Clin Orthop Relat Res 1996;329:194-8.

25. Protas M, Davis M, Bernard S, Alonso F, Moisi M, Oskouian RJ, et al. Sacroiliac Screw Fixation: A Systematic Review of Complications and their Causes 2017;1:30-6.

26. Zwingmann J, Hauschild O, Bode G, Südkamp NP, Schmal H. Malposition and revision rates of different imaging modalities for percutaneous iliosacral screw fixation following pelvic fractures: a systematic review and meta-analysis. Arch Orthop Trauma Surg 2013;133:1257-65.

27. Osterhoff G, Ossendorf C, Wanner GA, Simmen HP, Werner CM Percutaneous iliosacral screw fixation in S1 and S2 for posterior pelvic ring injuries: technique and perioperative complications. Arch Orthop Trauma Surg 2011;131:809-13. 